\title{
Possible Role of Endogenous Prostaglandins in Glucagon Secretion by Isolated Guinea-Pig Islets
}

\author{
A. S. Luyckx and P. J. Lefebvre \\ Diabetes Section, Institute of Medicine, University of Liège, Liège, Belgium
}

\begin{abstract}
Summary. Previous studies have demonstrated that prostaglandins stimulate glucagon secretion in vitro and in vivo. The present work was aimed at investigating the influence of two inhibitors of prostaglandin synthesis, isopropyl-2 nicotinoyl-3 indole (L8027) and indomethacin, on basal and arginine- or noradrenaline-stimulated glucagon release from isolated guinea-pig islets incubated in the absence of glucose. L8027 $\left(10^{-4}\right.$ and $\left.10^{-5} \mathrm{~mol} / \mathrm{l}\right)$ did not alter basal glucagon release, blocked almost completely the glucagon response to arginine $\left(10^{-2} \mathrm{~mol} / \mathrm{l}\right)$, had no effect on the glucagon release induced by noradrenaline $\left(10^{-4} \mathrm{~mol} / \mathrm{l}\right)$, but reduced the stimulatory effect of a lower concentration of noradrenaline $\left(5.10^{-7} \mathrm{~mol} / \mathrm{l}\right)$. The kinetic study of this inhibitory effect demonstrated that (1) it necessitates preincubation of the islets with L8027 for 30 minutes before the addition of arginine, (2) after a short preincubation period (30 minutes) in the presence of L8027, removal of the inhibitor at the time of arginine stimulation resulted in enhanced glucagon response, (3) on the contrary, after a prolonged incubation period (75 min) with arginine and L8027, the inhibitory effect remained transiently detectable after removal of L8027. Indomethacin similarly blocked arginine- and noradrenaline-induced glucagon secretion. These results suggest that an intra-insular synthesis of prostaglandins is involved in the A cell response to arginine and noradrenaline.
\end{abstract}

Key words: Isolated islets, guinea-pig, prostaglandin synthesis, glucagon secretion, arginine, noradrenaline, indomethacin.

Previous studies have demonstrated that the prostaglandins $P G E_{1}, E_{2}$ and $F_{2 \alpha}$ stimulate the release of glucagon by the isolated perfused rat pancreas and augment the glucagon response to other secretagogues such as L-arginine [1]. On the other hand, Sacca and Perez [2] reported that $\mathrm{PGE}_{1}$ intravenous infusion significantly increased glucagon plasma levels in the rat while $\mathrm{PGA}_{1}$ had no effect. Although these results are in keeping with the hypothesis that prostaglandins (PGs) may be involved in the regulation of glucagon secretion, they do not clarify the possible role of intra-islet synthesis of PGs in the stimulussecretion coupling of A cells.

The present work was aimed at investigating the influence of inhibitors of PG synthesis on glucagon release by isolated guinea-pig islets incubated in vitro. The effects of two such inhibitors, L8027 (isopropyl-2 nicotinoyl-3 indole) $[3,4]$ and indomethacin [5] were tested under basal conditions as well as under conditions of stimulation by arginine and noradrenaline.

\section{Material and Methods}

\section{Separation of Guinea-Pig Islets}

Male guinea-pigs weighing $300-400 \mathrm{~g}$ were used. The animals, who had free access to food until the time of the experiment, were killed by a blow on the head immediately prior to removal of the pancreas. Islets were isolated by the collagenase technique $[6,7$, 8]. Small pieces originating from three pancreases were incubated in Hanks' solution which included $26 \mathrm{mg}$ collagenase (CLS IV Worthington Biochemical Corporation, New Jersey, USA.) in a total volume of $9 \mathrm{ml}$ at $37^{\circ} \mathrm{C}$ and shaken vigorously for 8-10 minutes. Yields of 400-500 islets were obtained from 3 pancreases. Digestion was stopped by diluting with chilled Hanks' buffer and washing 5 times with fresh buffer. The last precipitate, consisting of intact islets and small fragments of acinar tissue, was resuspended and examined in a Petri dish against a black background.

\section{Incubation of Islets}

Islets were identified under the stereo-microscope and drawn up with the aid of finely drawn Pasteur pipettes [7]. Two or three 


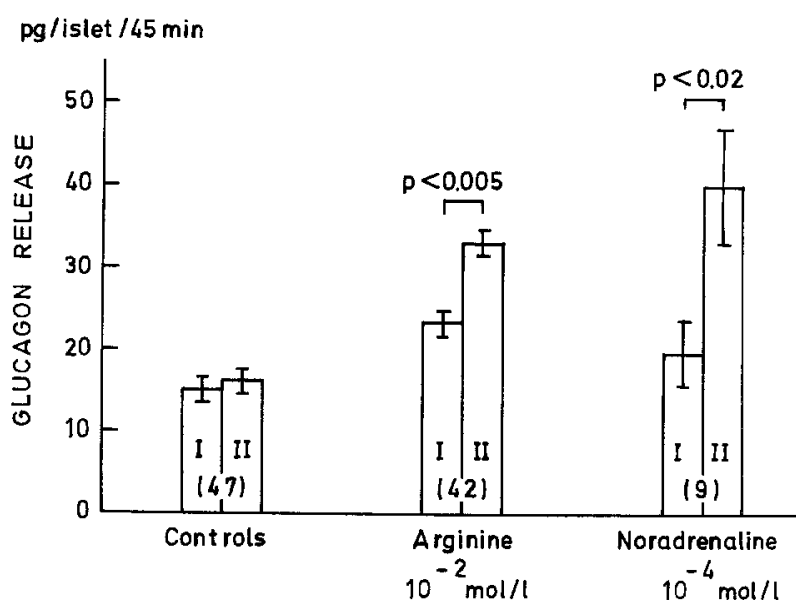

Fig. 1. Effect of arginine and noradrenaline on the glucagon release during the two successive periods of incubation. Results are expressed as mean \pm SEM. The number of incubation vials for each condition is indicated at the bottom of the columns

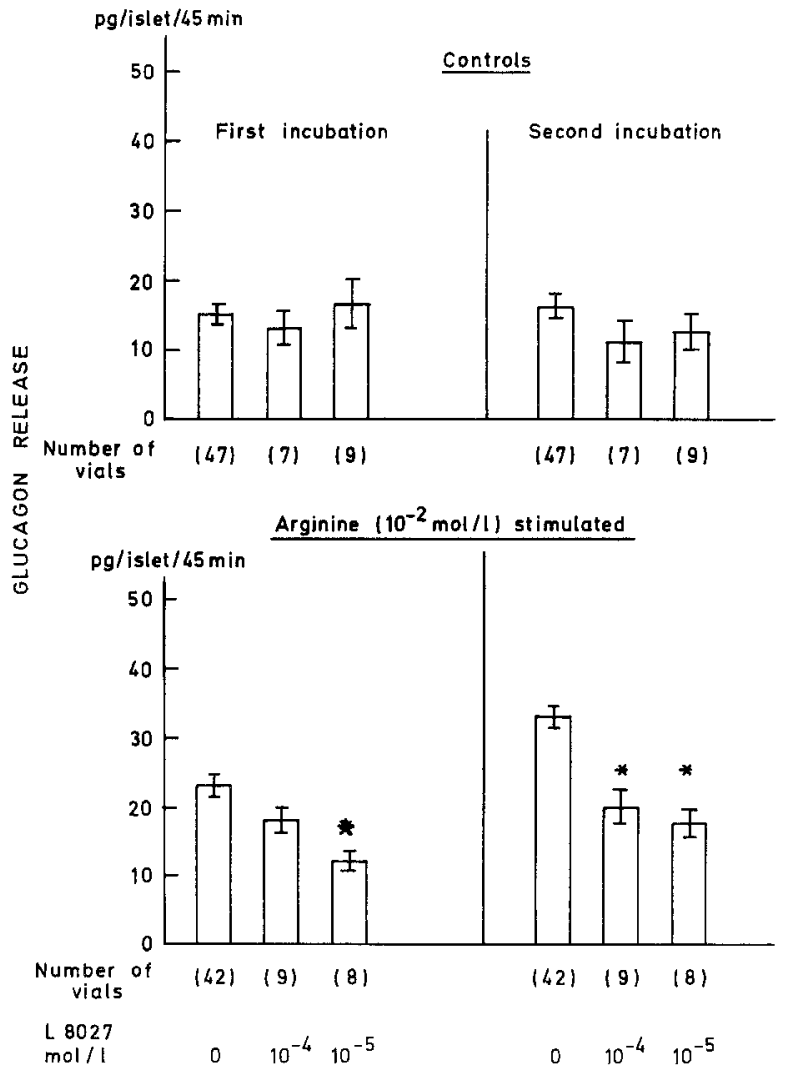

Fig. 2. Influence of L8027 on basal (upper panel) and argininestimulated (lower panel) glucagon release during the two successive periods of incubation. ${ }^{*} \mathrm{p}<0.001$ versus islets incubated in the absence of $\mathrm{L} 8027$ groups of 150-200 islets were then preincubated for $30 \mathrm{~min}$ in Packard vials containing $15 \mathrm{ml}$ of Gey and Gey buffer [9]. The flasks were stoppered with a rubber cap and the medium was thoroughly gassed with $\mathrm{O}_{2}-\mathrm{CO}_{2}(95: 5 \mathrm{v} / \mathrm{v})$ during the preincubation. At the end of the preincubation period, the groups of islets were transferred to Petri dishes and from there were picked out individually and distributed, in groups of 15 into Packard vials containing $2 \mathrm{ml}$ of the incubation medium (Incubation I). The flasks were stoppered, gassed for $5 \mathrm{~min}$ and incubated for $45 \mathrm{~min}$ in a water bath at $37.5^{\circ} \mathrm{C}$ with gentle shaking at $80 \mathrm{cycles} / \mathrm{min}$. The incubation medium was carefully removed at the end of the first incubation period and a second $45 \mathrm{~min}$ incubation was carried out under conditions identical to those of the first, with $2 \mathrm{ml}$ of fresh medium (Incubation II). At the end of the experiment, all the islets incubated in the same medium were pooled in $3 \mathrm{ml}$ of buffer and submitted to ultrasonic disruption for $30 \mathrm{sec}$. The resulting mixture was assayed for glucagon at a dilution $1 / 100$ or $1 / 200$ with the assay buffer.

\section{Incubation Medium}

The bicarbonate-buffer salt solution according to Gey and Gey [9] was used, containing in mmol/1 Na: $149 ; \mathrm{K}: 5.2 ; \mathrm{Cl}: 131 ; \mathrm{Mg}: 1.3$; $\mathrm{Ca}: 2$ and $\mathrm{HCO}_{3}: 27$. Bovine crystallised albumin (Armour Pharmaceutical Company, England) was added at a concentration of 2 $\mathrm{g} / \mathrm{l}$ and the $\mathrm{pH}$ was adjusted to 7.4. The medium was gassed by bubbling for at least $30 \mathrm{~min}$ with $\mathrm{O}_{2}-\mathrm{CO}_{2}(95: 5 \mathrm{v} / \mathrm{v})$ immediately before use. According to the basic experimental protocols, the secretagogues (either L-arginine monohydrochloride or L-noradrenaline, BDH Biochemicals Ltd, England) were present in the incubation medium during incubation periods I and II, while the inhibitors of prostaglandin synthesis (indomethacin and L8027) were added to the preincubation medium as well. Indomethacin (Merck, Sharp and Dohme, Haarlem, Nederland) and L8027 (Labaz, Bruxelles, Belgium) were dissolved in methanol 35.8 and $88.0 \mathrm{mg} / \mathrm{ml}$ respectively and then diluted in the incubation medium to reach the appropriate concentrations. Noradrenaline was first dissolved in buffer containing $6 \mathrm{~g} / 1$ ascorbic acid to reach a concentration of $1 \mathrm{mmol} / \mathrm{l}$ and this solution was diluted $1 / 10$ in the incubation medium immediately before use. In this case, methanol or ascorbic acid were always added to the incubation medium used for control islets. All incubations were carried out in the absence of glucose in order to favour glucagon secretion. Indeed, it has been reported that a glucose concentration as low as $2.5 \mathrm{mmol} / 1$ suppresses amino acid stimulated glucagon release by $50 \%[10]$.

\section{Assays}

Glucagon was measured by radioimmunoassay [11] using ${ }^{125} \mathrm{I}-$ glucagon (NEN, Boston, USA) as tracer and $30 \mathrm{~K}$ antiserum (Dr R. H. Unger, Dallas). The standard curve was prepared with MC pork glucagon (Batch 6770 , kindly given by Dr Schlichtkrull, Novo Copenhagen) dissolved in an aliquot of the incubation medium. The results must therefore be understood to be expressed as "pork-glucagon equivalents" since marked species differences exist between pork and guinea-pig glucagons [12].

\section{Calculations}

Glucagon release was calculated as $\mathrm{pg} / \mathrm{islet} / 45 \mathrm{~min}$. All data were expressed as mean \pm SEM and were analysed using the Student $t$ test for paired and non-paired data [13]. 
Table 1. Influence of the duration of the exposure of the islets to $L 8027\left(10^{-5} \mathrm{~mol} / \mathrm{l}\right)$ upon the subsequent glucagon release induced by arginine $(10 \mathrm{mmol} / \mathrm{l})$. Results are expressed as $\mathrm{pg} / \mathrm{islet} / 45 \mathrm{~min}$

\begin{tabular}{|c|c|c|c|c|c|c|}
\hline \multirow{2}{*}{$\begin{array}{l}\text { Experimental } \\
\text { Conditions }\end{array}$} & \multicolumn{3}{|c|}{ Presence of L8027 } & \multirow{2}{*}{$\begin{array}{l}\text { Number of } \\
\text { vials }\end{array}$} & \multirow{2}{*}{$\begin{array}{l}\text { First } \\
\text { incubation }\end{array}$} & \multirow{2}{*}{$\begin{array}{l}\text { Second } \\
\text { incubation }\end{array}$} \\
\hline & $\begin{array}{l}\text { PRE } \\
(30 \mathrm{~min})\end{array}$ & $\begin{array}{l}\text { I } \\
(45 \mathrm{~min})\end{array}$ & $\begin{array}{l}\mathrm{II} \\
(45 \mathrm{~min})\end{array}$ & & & \\
\hline A & - & - & - & 42 & $23.2 \pm 1.4$ & $32.9 \pm 1.5$ \\
\hline B & + & + & + & 8 & $11.9 \pm 1.3^{\mathrm{b}}$ & $17.5 \pm 1.9^{\mathfrak{c}}$ \\
\hline $\mathrm{C}$ & + & - & - & 8 & $31.5 \pm 5.5^{\mathrm{a}}$ & $47.8 \pm 5.1^{\mathrm{c}}$ \\
\hline $\mathrm{D}$ & - & + & + & 9 & $23.9 \pm 4.0$ & $25.9 \pm 5.0$ \\
\hline$E$ & + & + & - & 9 & $15.6 \pm 1.8^{b}$ & $13.7 \pm 1.5^{\mathrm{c}}$ \\
\hline
\end{tabular}

In all experimental conditions, arginine $10 \mathrm{mmol} / 1$ is present during incubations $I$ and $I I ;{ }^{\mathrm{a}} \mathrm{p}<0.05,{ }^{\mathrm{b}} \mathrm{p}<0.02,{ }^{\mathrm{c}} \mathrm{p}<0.001$ versus the corresponding incubation period in Condition $\mathrm{A}$

\section{Results}

\section{Influence of Arginine and Noradrenaline}

Figure 1 illustrates the influence of arginine and noradrenaline on glucagon release. Under control conditions, glucagon release averaged $15 \mathrm{pg} /$ islet $/ 45 \mathrm{~min}$ and was almost identical for incubations I and II. Arginine $10 \mathrm{mmol} / \mathrm{l}$ elicited a significant stimulation of glucagon release during incubation I ( $p<0.001$ versus controls) and the stimulation persisted and was significantly greater during incubation II $(\mathrm{p}<$ 0.005 versus incubation I). For noradrenaline $10^{-4}$ $\mathrm{mol} / \mathrm{l}$, the stimulation did not reach the level of statistical significance during incubation I but became highly significant during incubation II $(\mathrm{p}<0.001$ versus controls). Expressed as \% of the glucagon content of the islets, the glucagon release during the second incubation averaged $0.67 \%$ in $45 \mathrm{~min}$ under control conditions and $1.1 \%$ or $1.2 \%$ when the islets were stimulated by arginine $(\mathrm{p}<0.001)$ and noradrenaline $(\mathrm{p}<0.005)$ respectively.

\section{Influence of L8027 on Basal and Arginine-Stimulated Glucagon Release}

In this series of experiments (Fig. 2), L8027 was added at concentrations of $10^{-4}$ or $10^{-5} \mathrm{~mol} / 1$ to the medium used for preincubation as well as for incubations I and II. The two concentrations of L8027 did not significantly alter basal glucagon release. When arginine was added during incubations I and II, the glucagon release was moderately reduced during incubation I; paradoxically, this reduction was not statistically significant for L8027 $10^{-4} \mathrm{~mol} / \mathrm{l}$ but was unequivocal for L8027 $10^{-5} \mathrm{~mol} / \mathrm{l}(\mathrm{p}<0.001)$. Both concentrations of the inhibitor abolished arginineinduced glucagon release during incubation II $(\mathrm{p}<$ 0.001 versus islets preincubated and incubated in the absence of L8027).

\section{Influence of the Duration of Contact of the Islets with L8027 on the Arginine-Induced Glucagon Release}

The purpose of these experiments was to evaluate the time needed for L8027 inhibition of arginineinduced glucagon release to develop as well as to test the reversibility of this inhibition. Three conditions were used: L8027 added during preincubation alone (C), L8027 absent during preincubation but present during incubations $I$ and $I I$ (D), and L8027 added during preincubation and incubation I, but not during incubation II (E). For this last experiment, islets were washed carefully between incubations I and II. Table 1 compares the results obtained in conditions C, D and $E$ with the reference values of glucagon release obtained either in the absence (A) or in the presence (B) of L8027 during the whole experiment. When L8027 was present only during the preincubation period (C), there was no inhibition of the arginineinduced glucagon release; on the contrary, a significantly greater response to arginine was recorded ( $p<$ 0.05 during incubation I and $\mathrm{p}<0.001$ during incubation II versus absence of L8027). When L8027 was not present during the preincubation period and was only added together with arginine for incubations I and II, the arginine-induced glucagon release remained unaltered (condition D). Finally, careful washing of islets which had been incubated for 75 $\mathrm{min}$ in the presence of $\mathrm{L} 8027$ (30 min preincubation +45 min incubation I) did not restore their capacity to respond to arginine during incubation II (condition $\mathrm{E}$ ). Another series of experiments was designed in order to determine whether the inhibitory effect of L8027 [1] was completely or transiently irreversible and [2] was relatively specific for the arginine stimulus, leaving unaltered the response to noradrenaline. For this purpose, islets were preincubated for $75 \mathrm{~min}$ (instead of $30 \mathrm{~min}$ ) in the presence of a higher concentration of $\operatorname{L} 8027\left(10^{-4} \mathrm{~mol} / \mathrm{l}\right)$, 
Table 2. Influence of a prolonged preincubation $(75 \mathrm{~min})$ of the islets in the presence of L8027 upon the subsequent glucagon release induced by arginine alone and by arginine plus noradrenaline. Incubations themselves are carried out in the absence of $\mathbf{L} 8027$. Results are expressed as $\mathrm{pg} / \mathrm{islet} / 45 \mathrm{~min}$

\begin{tabular}{|c|c|c|c|c|c|}
\hline & Number of vials & First incubation & & Second incubation & \\
\hline $\begin{array}{l}\text { Islets preincubated }(75 \mathrm{~min}) \text { in the } \\
\text { absence of } \mathrm{L} 8027 \text { and then incubate } \\
\text { the presence of } \\
\text { A. Arginine } 10 \mathrm{mmol} / 1\end{array}$ & 8 & $50.0 \pm 4.0$ & & $45.7 \pm 2.6$ & \\
\hline $\begin{array}{l}\text { Islets preincubated }(75 \mathrm{~min}) \text { in the } \\
\text { presence of } \mathrm{L} 802710^{-4} \mathrm{~mol} / 1 \text { and } \\
\text { then incubated in the presence of: } \\
\text { B. Arginine } 10 \mathrm{mmol} / 1\end{array}$ & 7 & \} & $\mathrm{p}<0.025$ & $45.6 \pm 7.1$ & $\mathrm{p}<0.025$ \\
\hline $\begin{array}{l}\text { C. Arginine } 10 \mathrm{mmol} / \mathrm{l} \\
+ \\
\text { Noradrenaline } 10^{-4} \mathrm{~mol} / 1\end{array}$ & 7 & $67.2 \pm 7.2\}$ & $\mathrm{p}<0.005$ & $107.3 \pm 28.3\} \mathrm{p}<0.05$ & \\
\hline
\end{tabular}

Table 3. Influence of noradrenaline and L8027 upon the glucagon release by isolated guinea-pig islets. Results are expressed as pg/ islet $/ 45 \mathrm{~min}$

\begin{tabular}{llll}
\hline & & $\begin{array}{l}\text { First } \\
\text { Incubation }\end{array}$ & $\begin{array}{l}\text { Second } \\
\text { Incubation }\end{array}$ \\
\hline $\begin{array}{l}\text { Control medium } \\
\text { Control medium }+\end{array}$ & $\mathrm{n}=13$ & $11.1 \pm 1.9$ & $13.7 \pm 2.9$ \\
$\begin{array}{l}\text { Noradrenaline } 5.10^{-7} \mathrm{~mol} / 1 \\
\text { Control medium }+\end{array}$ & $\mathbf{n}=15$ & $21.7 \pm 1.9^{\mathrm{a}}$ & $24.4 \pm 2.4^{\mathrm{a}}$ \\
$\begin{array}{l}\text { Noradrenaline } 5.10^{-7} \mathrm{~mol} / 1 \\
\text { L8027 } 10^{-4} \mathrm{~mol} / 1\end{array}$ & & $19.4 \pm 1.8^{\mathrm{a}}$ & $18.4 \pm 2.2$ \\
\hline
\end{tabular}

a $\mathrm{p}<0.01$ versus control medium

Table 4. Influence of noradrenaline and indomethacin upon the glucagon release by isolated guinea-pig islets. Results are expressed as pg/islet $/ 45 \mathrm{~min}$

\begin{tabular}{lcll}
\hline & $\begin{array}{l}\text { Number } \\
\text { vials }\end{array}$ & $\begin{array}{l}\text { First } \\
\text { Incubation }\end{array}$ & $\begin{array}{l}\text { Second } \\
\text { Incubation }\end{array}$ \\
\hline $\begin{array}{l}\text { Control medium } \\
\begin{array}{l}\text { Control medium }+ \\
\text { noradrenaline } 10^{-4} \mathrm{~mol} / 1\end{array}\end{array}$ & 8 & $31.4 \pm 3.8$ & $31.7 \pm 2.8$ \\
$\begin{array}{l}\text { Control medium }+ \\
\text { noradrenaline } 10^{-4} \mathrm{~mol} / 1 \\
\text { indomethacin } 10^{-4} \mathrm{~mol} / \mathrm{l}\end{array}$ & 10 & $45.8 \pm 11.3$ & $49.4 \pm 7.5^{\mathrm{a}}$ \\
\hline
\end{tabular}

a $\mathrm{p}<0.05$ versus control medium; ${ }^{b} \mathrm{p}<0.05$ versus noradrenaline alone. The high glucagon release observed in this experiment is entirely due to the large size of the islets. For some unknown reason, their mean glucagon content was $5950 \mathrm{pg} /$ islet while the mean value for all other experiments was around $3000 \mathrm{pg} /$ islet. Expressed in \% of islet glucagon content, the release was similar to that reported in Figure 1 ( 0.54 and $0.67 \%$ respectively)

washed carefully, and then incubated for two successive periods, either in the presence of arginine alone $(10 \mathrm{mmol} / \mathrm{l})$ or in the presence of arginine plus noradrenaline $\left(10^{-4} \mathrm{~mol} / \mathrm{l}\right)$. As depicted in Table 2, islets preincubated with $\mathrm{L} 8027$ release significantly less glucagon in response to arginine than control islets

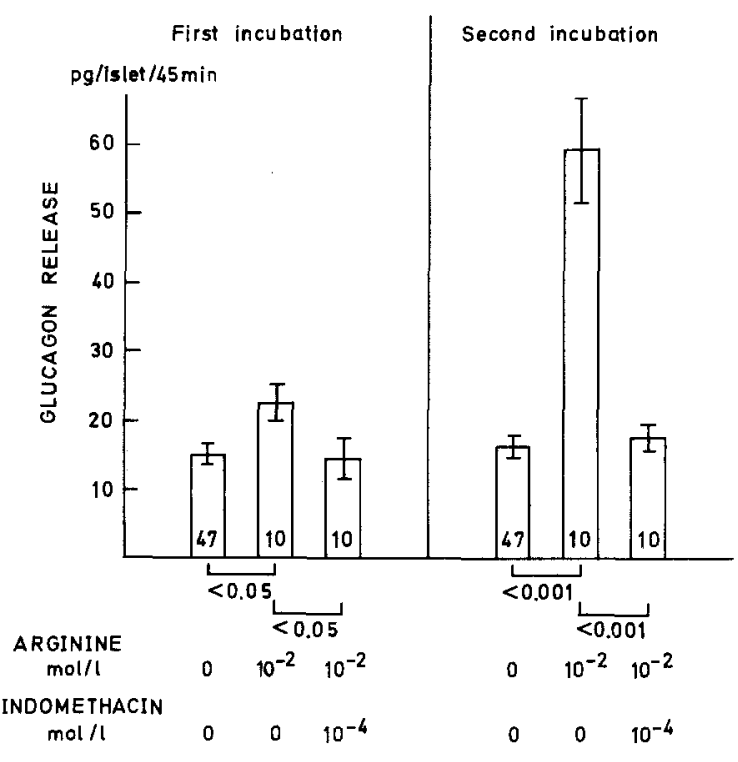

Fig. 3. Influence of indomethacin on arginine-stimulated glucagon release during the two successive periods of incubation

( $\mathrm{p}<0.025$ ) during the first incubation period, but completely recovered their sensitivity to arginine during the second incubation period (Condition $\mathrm{B}$ ). Moreover, noradrenaline $\left(10^{-4} \mathrm{~mol} / \mathrm{l}\right)$ was able to overcome the persistent inhibitory action of L8027 during the first incubation and to exert an additional stimulation above that of arginine during the second incubation (Condition C).

\section{Influence of L8027 on Noradrenaline-Induced Glucagon Release}

As already mentioned (see Fig. 1) noradrenaline $10^{-4}$ $\mathrm{mol} / \mathrm{l}$ increased glucagon release during incubation II 
from a control value of $16.2 \pm 1.3 \mathrm{pg} /$ islet $/ 45 \mathrm{~min}$ to $39.5 \pm 7.0, \mathrm{n}=9, \mathrm{p}<0.001)$. When L8027 was present during preincubation and incubations I and II, the noradrenaline-induced glucagon release was not significantly altered $(33.1 \pm 2.7 \mathrm{pg} / \mathrm{islet} / 45 \mathrm{~min}$, $\mathrm{n}=8)$. A lower concentration of noradrenaline $\left(5.10^{-7} \mathrm{~mol} / \mathrm{l}\right)$ was still capable of stimulating significantly glucagon release during the two incubation periods (Table 3 ). This effect was no more significant during the second incubation when the whole experiment was carried out in the presence of L8027 $\left(10^{-4}\right.$ $\mathrm{mol} / \mathrm{l})$.

\section{Influence of Indomethacin on Arginine- or Noradrenaline-Induced Glucagon Release}

The significant stimulation of glucagon release induced by arginine $10 \mathrm{mmol} / \mathrm{l}$ was completely blocked by indomethacin $10^{-4} \mathrm{~mol} / \mathrm{l}$. This inhibition was statistically significant for incubations I and II (Fig. 3). Similarly, indomethacin blocked the glucagon release stimulated by noradrenaline $10^{-4} \mathrm{~mol} / \mathrm{l}$ (Table 4). The experimental protocol used for indomethacin was similar to that used for L8027 in Fig. 2: the inhibitor of PG synthesis was present during preincubation, and incubations I and II whereas arginine or noradrenaline were added after preincubation and thus present during incubations I and II.

\section{Discussion}

L8027 is a compound with anti-inflammatory properties which has been shown to inhibit the synthesis of $\mathrm{PGE}_{2}$ and $\mathrm{PGF}_{2 \alpha}$ [4]. The prostaglandin synthetase from microsomal preparations of bovine seminal vesicles is markedly inhibited by concentrations $5 \times$ $10^{-6}$ to $10^{-5} \mathrm{~mol} / 1 \mathrm{~L} 8027$ [4].

The present work demonstrates that this compound does not alter basal glucagon release, blocks almost completely the glucagon response to arginine, reduces the glucagon release evoked by a low noradrenaline concentration, but does not alter the stimulatory effect of a high noradrenaline concentration in the incubation medium. Indomethacin, a classical inhibitor of PG synthesis (review in 5), similarly abolishes arginine- and noradrenaline-induced glucagon release. In the case of L8027, we observed that the inhibitory action was not immediate and was only displayed when the islets were preincubated with the compound for 30 minutes before arginine was added. Moreover, a significant rebound phenomenon was observed when, after 30 minutes contact, L8027 was removed at the time of arginine stimulation. A more prolonged incubation of the islets with L8027 (75 minutes) resulted in a transient insensitivity to arginine despite the removal of the inhibitor. That the islets retain their response to noradrenaline and subsequently recover their sensitivity to arginine suggests that these observations do not correspond to a damaged islet system but rather to various states of interaction between L8027 and the prostaglandin synthetase system but our protocol does not bring any information about the molecular mechanism(s) underlying this interaction. Although the possibility exists that indomethacin and L8027 might have membrane effects per se, independent of their specific action on the prostaglandin synthetase system, the most likely explanation for our results is that endogenously synthesized prostaglandins are involved in the A cell secretory response. Thus, not only can exogenous $\mathrm{PGE}_{1}, \mathrm{PGE}_{2}$ and $\mathrm{PGF}_{2 \alpha}$ stimulate the release of glucagon, as demonstrated by Pek et al. [1], but we suggest that prostaglandins could be generated within the islets and exert their biological effect locally. Another possibility is that, besides prostaglandins themselves, other derivatives of arachidonic or dihomo- $\gamma$-linolenic acids metabolism such as endoperoxides, thromboxanes or prostacyclins are involved. Several studies have suggested that some interaction of catecholamines and prostaglandins may occur. This was extensively studied on the kidney where it was shown that renal nerve stimulation, as well as norepinephrine infusion, resulted in a prostaglandin release [14]. Using the isolated perfused rabbit kidney, Needleman et al. [15] demonstrated that the prostaglandin release was blocked with indomethacin and $\alpha$-adrenergic blockade with phenoxybenzamine. A similar $\alpha$-adrenergic blockade on splenic nerve stimulation-induced prostaglandin release was reported by Ferreira et al. [16]. Confirming previous results $[17,18,19]$ we have demonstrated here that noradrenaline stimulates glucagon release. Both inhibitors of prostaglandin synthesis interfere with this stimulatory effect, but indomethacin seems more potent than L8027. One could speculate that prostaglandins are involved in the activation of $\mathrm{A}$ cell adenylate cyclase by catecholamines. In fact, this hypothesis would be in agreement with previous results obtained with a rat islet membrane adenylate cyclase and suggests that hormone-receptor units may be influenced by $\mathrm{PGE}_{1}$ [20].

Finally, although isolated guinea-pig islets have proven to be a valuable model for studying glucagon secretion by several group of investigators $[8,21,22]$, the possible species specificity of the phenomena must be taken into consideration.

Acknowledgements. We are indebted to Dr D. Binder for his help in preparing this manuscript, to Dr R. H. Unger for the supply of $30 \mathrm{~K}$ antiserum, to Mrs Cartenstadt and Miss Y. Claessens for their skilled assistance and to Mrs Vaessen-Petit for secretarial help. 


\section{References}

1. Pek, S., Tai, T-Y., Elster, A.: Stimulatory effects of prostaglandins E-1, E-2 and F-2-alpha on glucagon and insulin release in vitro. Diabetes (in press)

2. Sacca, L., Perez, G.: Influence of prostaglandins on plasma glucagon levels in the rat. Metabolism 25, 127-130 (1976)

3. Descamps, M., Inion, H., De Vogelaer, H., Charlier, R., Colot, M., Van Damme, M.: Recherches dans la série des indoles. I. Une nouvelle classe d'agents anti-inflammatoires potentiels de caractère basique: les indolyl-3 pyridyl cétones. Chim. Thér. 8, 173-177 (1973)

4. Duvivier, J., Wolf, D., Heusghem, C.: Enzymatic properties of prostaglandin synthetase from bovine seminal vesicles. Biochimie 57, 521-528 (1975)

5. Pong, S. S., Levine, L.: Prostaglandin synthetase systems of rabbit tissues and their inhibition by nonsteroidal antiinflammatory drugs. J. Pharmacol. Exp. Ther. 196, 226 (1976)

6. Lacy, P.E., Kostianovsky, M.: Method for the isolation of intact islets of Langerhans from the rat pancreas. Diabetes 16, 35-39 (1967)

7. Howell, S. L., Taylor, K. W.: Effects of glucose concentration on incorporation of $\left[{ }^{3} \mathrm{H}\right]$ leucine into insulin using isolated mammalian islets of Langerhans. Biochim. Biophys. Acta 130, 519-521 (1966)

8. Edwards, J. C., Howell, S. L., Taylor, K. W.: Radioimmunoassay of glucagon released from isolated guinea-pig islets of Langerhans incubated in vitro. Biochim. Biophys. Acta 215, 297-309 (1970)

9. Gey, G. O., Gey, M. K.: The maintenance of human normal cells and tumor cells in continuous culture. Am. J. Cancer 27, 45-76 (1936)

10. Pagliara, A. S., Stillings, S. S., Hover, B. A., Martin, D. M., Matschinsky, F. M.: Glucose modulation of amino acidinduced glucagon and insulin release in the isolated perfused rat pancreas. J. Clin. Invest. 54, 819-832 (1974)

11. Luyckx, A. S.: Immunoassays for glucagon. In: Glucagon. Molecular physiology. Clinical and therapeutic implications. Lefebvre, P. J., Unger, R. H. (eds), p. 285-298. Oxford: Pergamon Press 1972

12. Sundby, F.: Species variations in the primary structure of glucagon. Metabolism 25 [Suppl. 1], 1319-1322 (1976)

13. Snedecor, G. W.: Statistical methods, 5th ed. Ames: Iowa State University Press 1976
14. Flamenbaum, W., Kleinman, J. G.: Prostaglandins and renal function, or "A trip down the rabbit hole". In: The prostaglandins. Ramwell, P. W. (ed.), p. 267-328. New York, London: Plenum Press 1977

15. Needleman, P., Douglas, J. R. Jr., Jakschik, B., Stoeklein, P. B., Johnson, E. M., Jr.: Release of renal prostaglandin by catecholamines: Relationship to renal endocrine function. $J$. Pharmacol. Exp. Ther. 188, 453 (1974)

16. Ferreira, S. H., Moncada, S., Vane, J. R.: Some effects of inhibiting endogenous prostaglandin formation on the response of the cat spleen. Br. J. Pharmacol. 47, 48 (1973)

17. Leclercq-Meyer, V., Brisson, G. R., Malaisse, W. J.: Effect of adrenaline and glucose on release of glucagon and insulin in vitro. Nature 231, 248-249 (1971)

18. Gerich, J.E., Karam, J.H., Forsham, P.H.: Stimulation of glucagon secretion by epinephrine in man. J. Clin. Endocrinol. Metab. 37, 479-481 (1973)

19. Iversen, J.: Adrenergic receptors and the secretion of glucagon and insulin from the isolated, perfused canine pancreas. $\mathbf{J}$. Clin. Invest. 52, 102-116 (1973)

20. Thompson, W. J., Johnson, D. G., Williams, R. H.: Hormonal regulation of pancreatic islet adenyl cyclase. Biochemistry 15, 1658-1663 (1976)

21. Edwards, J.C., Taylor, K. W.: Fatty acids and the release of glucagon from isolated guinea-pig islets of Langerhans incubated in vitro. Biochem. Biophys. Acta 215, 310-315 (1970)

22. Ostenson, C.-G., Anderson, A., Brolin, S. E., Petersson, B., Hellerström, C.: Effects of insulin on the glucagon release, glucose utilization and ATP content of pancreatic A cells of the guinea pig. In: Glucagon: its role in physiology and clinical medicine. Foà, P. P., Bajaj, J. S., Foà, N. L. (eds.) p. 243-254. New York, Heidelberg, Berlin: Springer 1977

Received: March 23, 1978,

and in revised form: July 10,1978

A. S. Luyckx

Institute of Medicine

Hôpital de Bavière

Boulevard de la Constitution, 66

$\mathrm{B}-4020$ Liège

Belgium 